\title{
Temperature Based Optimization of Friction Stir Welding of AA 6061 Using GRA Synchronous With Taguchi Method
}

Eyob Messele ( $\sim$ Eyob.Messele@bdu.edu.et)

National Taiwan Institute of Technology: National Taiwan University of Science and Technology https://orcid.org/0000-0003-4660-6262

Assefa Asmare Tsegaw

\section{Research Article}

Keywords: Friction Stir Welding, Taguchi, GRA, AA 6061, Microstructure, Transient thermal

Posted Date: September 8th, 2021

DOI: https://doi.org/10.21203/rs.3.rs-841292/v1

License: (1) This work is licensed under a Creative Commons Attribution 4.0 International License. Read Full License 


\title{
Temperature based optimization of Friction Stir Welding of AA 6061 using GRA Synchronous with Taguchi method
}

\author{
Eyob Messele Sefene ${ }^{a *}$ and Assefa Asmare Tsegaw ${ }^{a}$ \\ ${ }^{a}$ Bahir Dar Institute of Technology, Faculty of Mechanical and Industrial Engineering, Bahir Dar-Ethiopia, 6000. \\ Corresponding email: Eyob.Messele@bdu.edu.et
}

\begin{abstract}
One of the recent novel joining mechanisms in the solid-state-welding process is Friction Stir Welding (FSW). The process is extensively used in joining similar and dissimilar materials as well. This research studied and found the optimum process parameters of FSW based on the temperature simulation results on a $5 \mathrm{~mm} 6061 \mathrm{Al}$ alloy sheet with a butt joint configuration. Steady-state heat transfer analysis was performed using a transient thermal workbench to predict and identify the optimum parameters grounded on the simulation welding temperature result. The parameters are optimized using the hybrid Taguchi L9 orthogonal array and Grey relation analysis method with a larger is better quality characteristic. Mechanical properties of the weld joints' such as hardness and tensile strength, were studied at an ambient temperature. The result revealed that a higher rotational speed with a minimum traverse speed and taper threaded tool pin impart the optimum parameter settings. Analysis of variance (ANOVA) was carried out also to determine the effects of each process parameter. At a $95 \%$ confidence interval, rotational and traverse speeds show significant characteristics. The joint efficiency reached $92.25 \%$ of the base metal at a maximum welding temperature. Additionally, the microstructure of the stir weld zone of the specimen was studied as well. Metallographic Characterization carried out using Scanning Electron Microscope (SEM) revealed the microstructure of the samples after the weld did not show any significant change with the base metal. Furthermore, this study scheme can be extended to thick non-ferrous, ferrous, and metal-based composite materials, too.
\end{abstract}

Keywords: Friction Stir Welding. Taguchi. GRA. AA 6061. Microstructure. Transient thermal

\section{Introduction}

The firm's everlasting joining of materials is one of the key measures in the engineering processes. Fusion welding is one of in the record, usually used in the conventional joining practices. Unfortunately, this method is pigeonholed by high-temperature gradients, leading to high thermal stress and prompt solidification, which escalates the occurrence of the segregation phenomenon [1]. As natural resources grow increasingly scarce, novel joining procedures are being developed to mitigate the adverse effects of traditional fusion processes. Furthermore, the demand for lightweight and high-strength structures continuously expands to reduce fuel consumption and enhance cargo capacity in the transportation system [2-4]. The use of a smart joining process can diminish the weight of the adding elements on the components. Also, the latest and advanced joining process offers several benefits, particularly for the joining of lightweight materials, among which Friction Stir Welding (FSW) is a prominent joining process [5, 6]. It is a solid-state joining process developed by W. Thomas and E. Nicholas at the Welding Institute (TWI) in Cambridge, United Kingdom, in 1991. The process is appropriate for welding ferrous and non-ferrous materials, especially for soft materials like aluminum, copper, nickel, titanium, and others are highly recommended [7-10]. The application area of this process is widely used in the nuclear industry for repairing the crack and construction of temporary structures where decommissioning is required [11], in the transportation industry such as aviation, maritime, and automotive industries for enhancing the weight of the joint [12], joining of high-density plastic materials like polyethylene, polyamide 6 and polyvinyl chloride materials [13]. Nowadays, FSW can be extended in metal matrix composite material joining processes [14]. For instance, the aviation industry uses AA 6061 to make commercial and military aircraft parts such as wings, fuselages, and airframe mountings [15-17]. Furthermore, most transportation sectors such as aviation, automotive, and Maritimes use friction stir welding to reduce the manufacturing time of components, enhance the thermo-mechanical properties, boost the joint strength compared to fusion welding, and minimize the weight of weld joints [18]. AA 6061 and friction stir welding are essential materials and joining processes in the transportation industry. However, a recent subject of interest is joining AA 6061 utilizing FSW, requiring proper control process parameters. Furthermore, in the FSW process, inappropriate process parameters impact the joint's mechanical qualities [19]. As a result, this article aims to discover the best process parameters for enhancing the highest hardness and tensile strength of the target materials. According to the study [20], the maximum temperature created by in the FSW process ranges from 70-90\% of the melting temperature of the welding material. This study established a novel approach for identifying the optimum parameters of FSW using a transient thermal simulation. The experiment has conducted the parameters, and their levels temperature results in the simulation are in the range of 70-90\% of the specimen melting point. The hybrid Grey Relational Analysis and Taguchi method was utilized for optimizing and validating the experimental results. The result revealed that the experimental temperature results are very close to the predicted simulation temperature results. 


\section{Experimental method}

\subsection{Experimental devices and materials}

This study used AA 6061 sheet with a dimension of 101.6 x 50 x 5 mm (LxWxT). Table 1 provide the chemical composition, mechanical, and thermos-physical properties of the materials. To minimize the residual stress induced in the material during the cutting process, used a hand hacksaw and sliced at an equal dimension depicted above. The two mating materials are welded with butt joint configurations at the faying surface using high-precision XHS7145 vertical CNC milling machines considered as an FSW machine illustrated in Figure 1. According to Taguchi L9 orthogonal array layout and GRA method, different parameters were carried out, that depicted in

Table 4. The welding temperature in advancing and retreating sides are measured using K-type thermocouples at the center point of the welding specimen. The tensile strength sample was prepared according to ASTM E8-04 requirements using a metalcraft VMBS 1610 band saw machine. Moreover, the tensile strength of the welded samples is examined using a computer-controlled universal testing machine (model HUT-600). The hardness of the joints is measured using a Rockwell hardness testing machine in scale HRA.

Table 1. 6061 aluminum alloy chemical composition

\begin{tabular}{ccccccc}
\hline Material & $\mathrm{Mg}$ & $\mathrm{Si}$ & $\mathrm{Fe}$ & $\mathrm{Cr}$ & $\mathrm{Cu}$ & $\mathrm{AL}$ \\
\hline AA 6061 & $0.92 \%$ & $0.6 \%$ & $0.33 \%$ & $0.18 \%$ & $0.25 \%$ & $97.6 \%$ \\
\hline
\end{tabular}

Table 2. Mechanical properties of AA 6061 [21]

\begin{tabular}{cccc}
\hline Material & Yield strength (MPa) & Ultimate tensile strength (MPa) & Hardness (HRA) \\
\hline AA 6061 & 276 & 310 & 40 \\
\hline
\end{tabular}

Table 3. Thermo-physical properties of $6061 \mathrm{Al}$ alloy [22]

\begin{tabular}{cccc}
\hline $\begin{array}{c}\text { Density } \\
\left(\mathrm{Kg} / \mathrm{mm}^{3}\right)\end{array}$ & Melting point (C) & $\begin{array}{c}\text { Thermal conductivity (W/m- } \\
\mathrm{k})\end{array}$ & $\begin{array}{c}\text { Specific heat }(\mathrm{J} / \mathrm{Kg}- \\
\left.{ }^{\circ} \mathrm{C}\right)\end{array}$ \\
\hline 68.9 & 652 & 167 & 0.896 \\
\hline
\end{tabular}

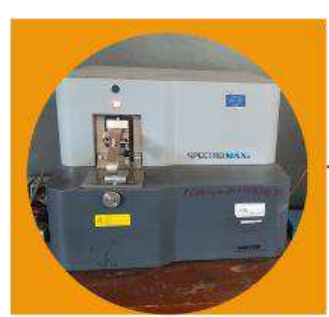

Spectrometer (MAXx)

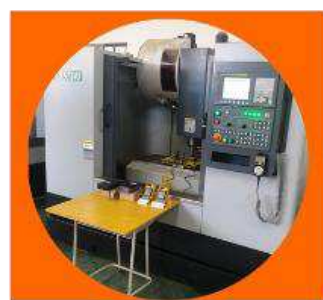

Experimental setup of FSW

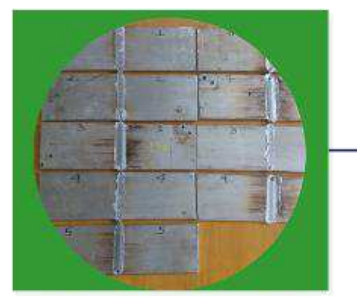

Friction Stir Welded specimen

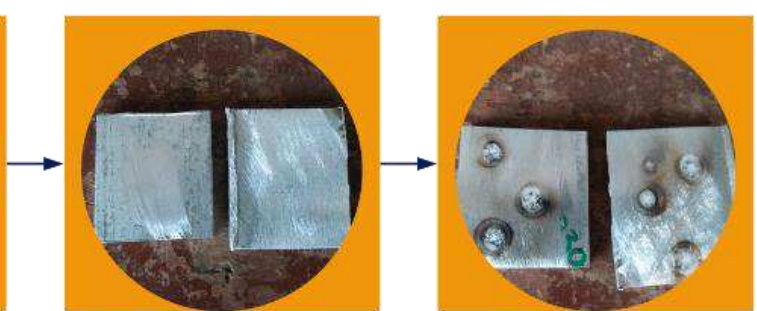

Before chemical composition test

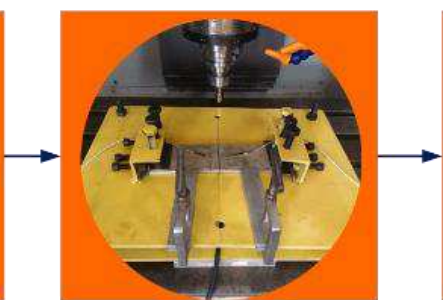

Before welding

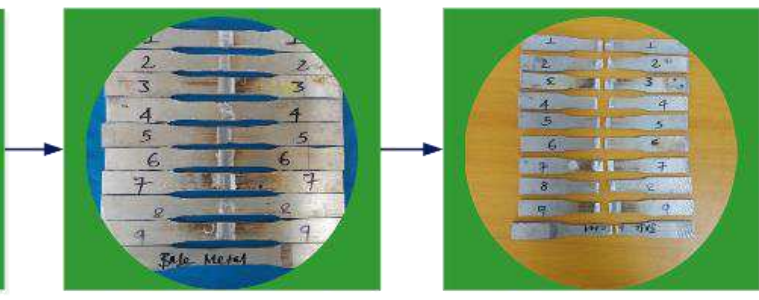

Before tensile test
After chemical composition test

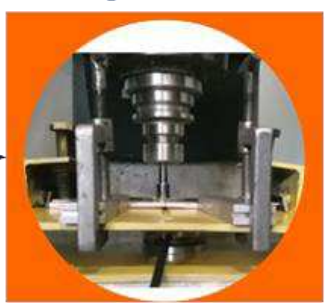

During welding

After tensile test

Figure 1. Overall experimental setup of FSW and testing of the specimen 
Table 4. Process parameters and their levels

\begin{tabular}{cccc}
\hline Parameters & \multicolumn{3}{c}{ Levels } \\
& 1 & 2 & 3 \\
\hline Tool pin profile & Cylindrical Threaded & Tri-flute Threaded & Taper Threaded \\
Welding speed & 37.5 & 42.5 & 47.5 \\
Rotational speed & 900 & 1200 & 1400 \\
\hline
\end{tabular}

\section{Numerical Modeling}

The creation and dispersion of heat in friction stir welding is an essential phenomenon, and enough heat generation is required for getting sound welding [23]. This simulation work has been done to predict the temperature results in the range of 70-90\% of the welding specimen for selecting the optimum parameters to minimize the trial and error methods during the DOE. Dimensions of the model have similar to the experimental welded sample. A steady-state heat transfer analysis was performed using a transient thermal workbench to forecast the AA 6061 temperature. A self-developed Application Customization Tool (ATC) has been used for addresses all the necessary parameters in FSW, such as shoulder diameter, pin diameter, tool rotational, and traverse speed. The model comprises a total number of hexahedral type elements, and nodes were 175392 and 205128, respectively. The region nearest to the faying surfaces is meshing with a fine cell size element, as shown in Figure 2, to increase the solution accuracy and the areas beyond the faying surface meshing with a coarse cell size element. The amount of heat generated per unit surface area at the tool-workpiece interface during the FSW process can be calculated [24-27] as:

$$
\frac{Q \propto}{A}(r)=\frac{3 Q_{\text {total }^{r}}}{2 \pi\left[\left(R_{\text {shoulder }}^{3}-R_{\text {probe }}^{3}\right)(1+\text { tan } \alpha)+R_{\text {probe }}^{3}+3 R_{\text {probe }}^{2} H_{\text {probe }}\right.}
$$

Where: $\alpha$ is the shoulder cone angle and $Q_{\text {total }}$ is total heat generation, and it is given by:

$$
\begin{gathered}
Q_{\text {total }=\frac{2}{3} \pi \omega\left[\delta \tau_{\text {yield }}+(1-\delta) \mu P\right]} \\
{\left[\left(R_{\text {shoulder }}^{3}+R_{\text {probe }}^{3}\right)(1+\text { tan } \alpha)+R_{\text {probe }}^{3}+3 R_{\text {probe }}^{2} H_{\text {probe }}\right.}
\end{gathered}
$$

Where: $\mathrm{P}$ is contact pressure, $\mu$ is friction coefficient, $\omega$ is the angular velocity of the tool, $\mathrm{r}$ is the radial distance from the rotational axis, $R_{\text {shoulder }}$ is shoulder radius, $R_{\text {probe }}$ is probe radius, $H_{\text {probe }}$ is probe height, $\tau_{\text {yield }}$ are yield strength and $\delta=\frac{\omega_{\text {matrix }}}{\omega_{\text {tool }}}$ and its value varies between 0 and 1 .

The basic form of the heat flux equation, which ignores the heat created by the probe,

$$
\frac{Q}{A}(r)=\frac{3 Q_{\text {total }} r}{2 \pi R_{\text {shoulder }}^{3}(1+\tan \alpha)}
$$

For flat shoulder can be written as

$$
\frac{Q}{A}(r)=\frac{3 Q_{\text {total }^{r}}}{2 \pi R_{\text {shoulder }}^{3}}
$$

The heat generated by the pin surface is assumed to be volumetric heat flux and can be represented by

$$
\frac{Q}{V_{\text {probe }}}(r)=\frac{3 Q_{\text {total }}{ }^{2}}{\pi\left(R_{\text {shoulder }}^{3}+3 R_{\text {probe }}^{2} H_{\text {probe }}\right)}
$$

In this model, we used a flat shoulder tool. All the temperatures generated from the specimen are modeled using heat flux. The maximum temperature has reached $559.9{ }^{\circ} \mathrm{C}$ at the faying surface of the sample. The transient thermal simulation at different time travels is illustrated in Figure 3. 


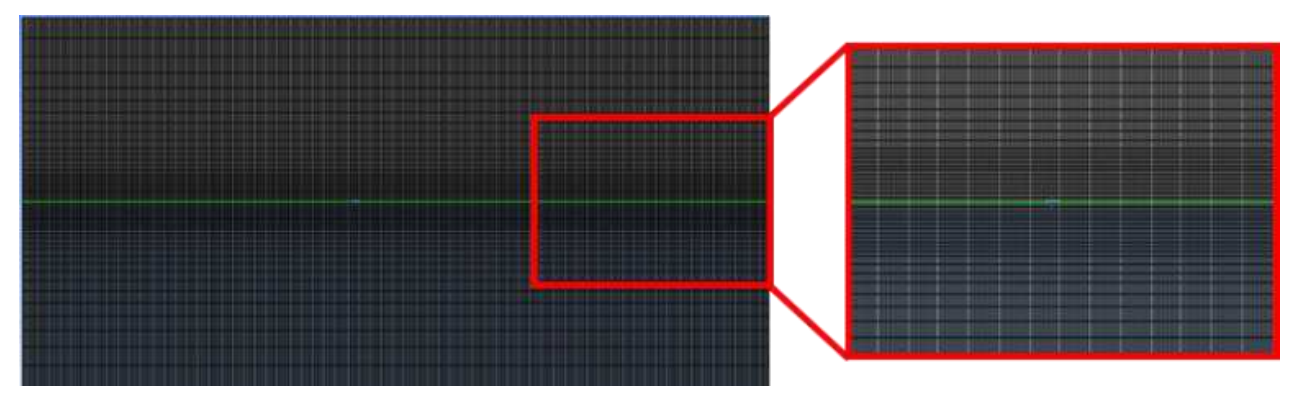

Figure 2. Finite element mesh for FSW specimen
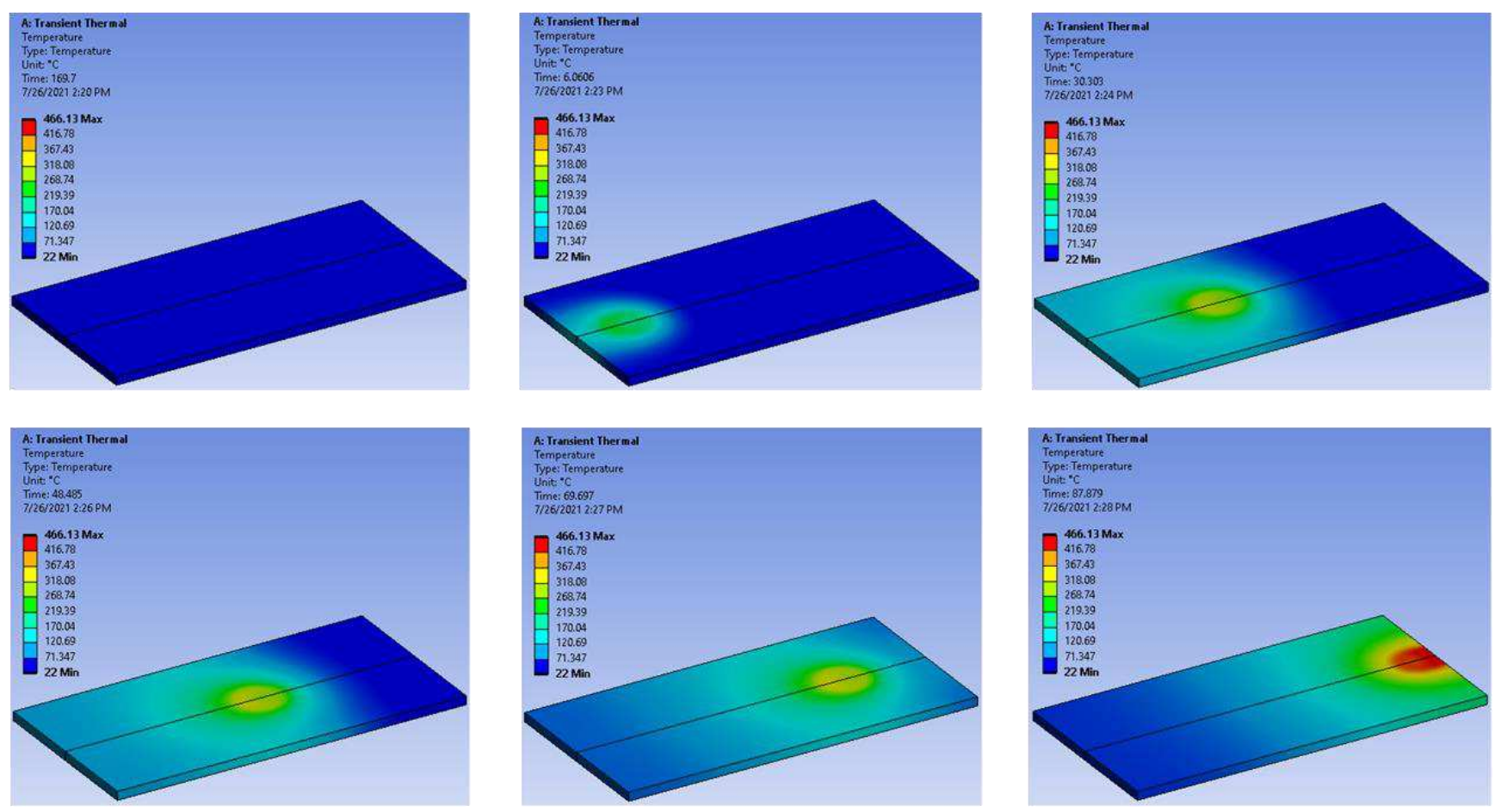

Figure 3. Temperature distribution at a different time travel speed

Table 5. Taguchi L9 based GRA parameter setting and experimental results of tensile strength, hardness, and temperature

\begin{tabular}{ccccccccc}
\hline Exp. N ${ }^{\text {o. }}$ & $\begin{array}{c}\text { Tool Profile } \\
\text { (Type) }\end{array}$ & $\begin{array}{c}\text { Welding } \\
\text { Speed } \\
(\mathrm{mm} / \mathrm{min})\end{array}$ & $\begin{array}{c}\text { Rotational } \\
\text { Speed } \\
(\mathrm{mm} / \mathrm{min})\end{array}$ & $\begin{array}{c}\text { UTS } \\
(\mathrm{Mpa})\end{array}$ & HRA & $\begin{array}{c}\text { Simulation } \\
\text { results of } \\
\text { temperature } \\
\left({ }^{\circ} \mathrm{C}\right)\end{array}$ & $\begin{array}{c}\text { Experimental } \\
\text { results of } \\
\text { temperature }\left({ }^{\circ} \mathrm{C}\right)\end{array}$ & $\begin{array}{c}\text { \% of temperature } \\
\text { Variation }\end{array}$ \\
\hline 1 & Cylindrical & 37.5 & 900 & 261 & 62.63 & 475.1 & 483.2 & 1.7 \\
2 & Cylindrical & 42.5 & 1200 & 266 & 64.30 & 500.6 & 499.7 & 0.2 \\
3 & Cylindrical & 47.5 & 1400 & 269 & 68.40 & 497.3 & 503.2 & 1.2 \\
4 & Tri-flute & 37.5 & 1200 & 271 & 70.23 & 503.6 & 509.1 & 1.1 \\
5 & Tri-flute & 42.5 & 1400 & 274 & 70.56 & 549.9 & 544.5 & 1.0 \\
6 & Tri-flute & 47.5 & 900 & 210 & 51.70 & 327.9 & 334.5 & 2.0 \\
7 & Taper Threaded & 37.5 & 1400 & 286 & 77.80 & 559.9 & 554.0 & 1.1 \\
9 & Taper Threaded & 42.5 & 900 & 242 & 54.70 & 473.1 & 476.1 & 0.6 \\
\hline
\end{tabular}




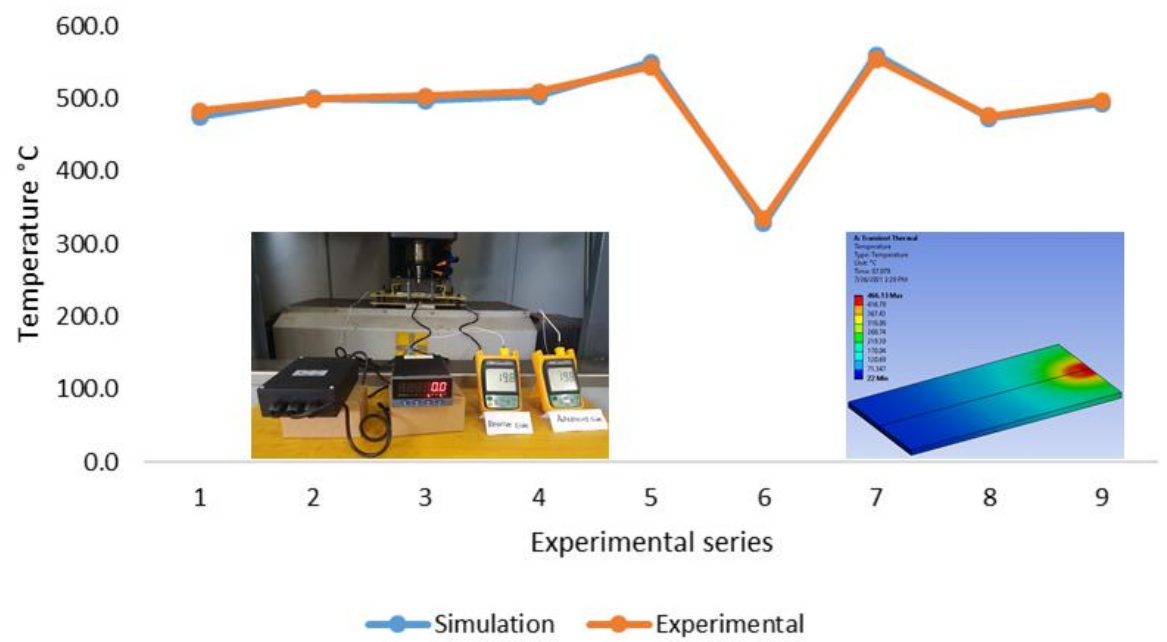

Figure 4. Experimental vs. Simulation results of temperature variations

\section{Statistical Analysis}

\subsection{Taguchi method}

The Taguchi approach is highly effective and widely used to improve process parameters without eliminating noises. This method uses a specially designed orthogonal array to minimize the number of experiments without compromising the main and interaction effect of the parameters [28, 29]. It uses the Signal to Noise ratio (S/N) as a quality criterion, and it is divided into three categories: larger is better, nominal is best, and smaller is better. This study used an L9 orthogonal array layout with a larger is better quality criterion summarized in Table 6 for both hardness and tensile responses. Equation 6 was used to generate a larger is a better criterion.

$$
\frac{S}{N}(\eta)=-10 \log 10 \frac{1}{n} \sum_{i=1}^{n} \frac{1}{y^{2}{ }_{i j k}}
$$

Where $\mathrm{n}$ is the number of replications and $\mathrm{y}_{\mathrm{ijk}}$ is the response value of the $\mathrm{i}^{\text {th }}$ performance characteristic in the $\mathrm{j}^{\text {th }}$ experiment at the $\mathrm{k}^{\text {th }}$ trial.

Table 6. Experimental results with its S/N ratio

\begin{tabular}{cccccc}
\hline No & Tool Profile & Welding Speed & $\begin{array}{c}\text { Rotational } \\
\text { Speed }\end{array}$ & UTS & HRA \\
\hline 1 & Cylindrical & 37.5 & 900 & 261 & 62.63 \\
2 & Cylindrical & 42.5 & 1200 & 266 & 64.30 \\
3 & Cylindrical & 47.5 & 1400 & 269 & 68.40 \\
4 & Tri-flute & 37.5 & 1200 & 271 & 70.23 \\
5 & Tri-flute & 42.5 & 1400 & 274 & 70.56 \\
6 & Tri-flute & 47.5 & 900 & 210 & 51.70 \\
7 & Taper Threaded & 37.5 & 1400 & 286 & 77.80 \\
8 & Taper Threaded & 42.5 & 900 & 242 & 54.70 \\
9 & Taper Threaded & 47.5 & 1200 & 261 & 63.44 \\
\hline
\end{tabular}

\subsection{Grey Relation Analysis for multi-objective optimization (GRA)}

One of the limitations of the Taguchi method is only used for a single response study. This study uses hybrid Taguchi and Grey Relational Analysis (GRA) to study the multi-response optimization process. This statistical analysis is highly effective for the multi-response optimization process, and it can be used to solve complex interrelationships between several responses [30]. This statistical analysis method has five basic steps illustrated in Figure 5 to find the optimum values of the target responses [31, 32]. 


\subsection{Data normalization}

The first step in the grey relational analysis approach is to execute the grey relational generation, which involves normalizing the outcomes of the tests in the range of 0 to $1[33,34]$. This step is required when the sequence scatters range is too large, or the target direction sequences are different. If the response is maximized, then larger is better characteristics are intended for normalization to scale it into an acceptable range using Equation 7 [35]. Results of data normalizations are summarized in

Table 7 .

$$
x_{i}(k)=\frac{x_{i}^{0}(k)-\min x_{i}^{0}(k)}{\max x_{i}^{0}(k)-\min x_{i}^{0}(k)}
$$

Where $x_{i}(k)$ is the sequence after the data processing; $x_{i}{ }^{0}(k)$ is the original sequence of $\mathrm{S} / \mathrm{N}$ ratio, where $i=1,2 \ldots . \mathrm{m}$ and $\mathrm{k}=1,2 \ldots \mathrm{n}$; $\max x_{i}^{0}(\mathrm{k})$ is the largest value of $x_{i}^{0}(\mathrm{k}) ; \min x_{i}^{0}(\mathrm{k})$ is the smallest value of $x_{i}^{0}(\mathrm{k})$.

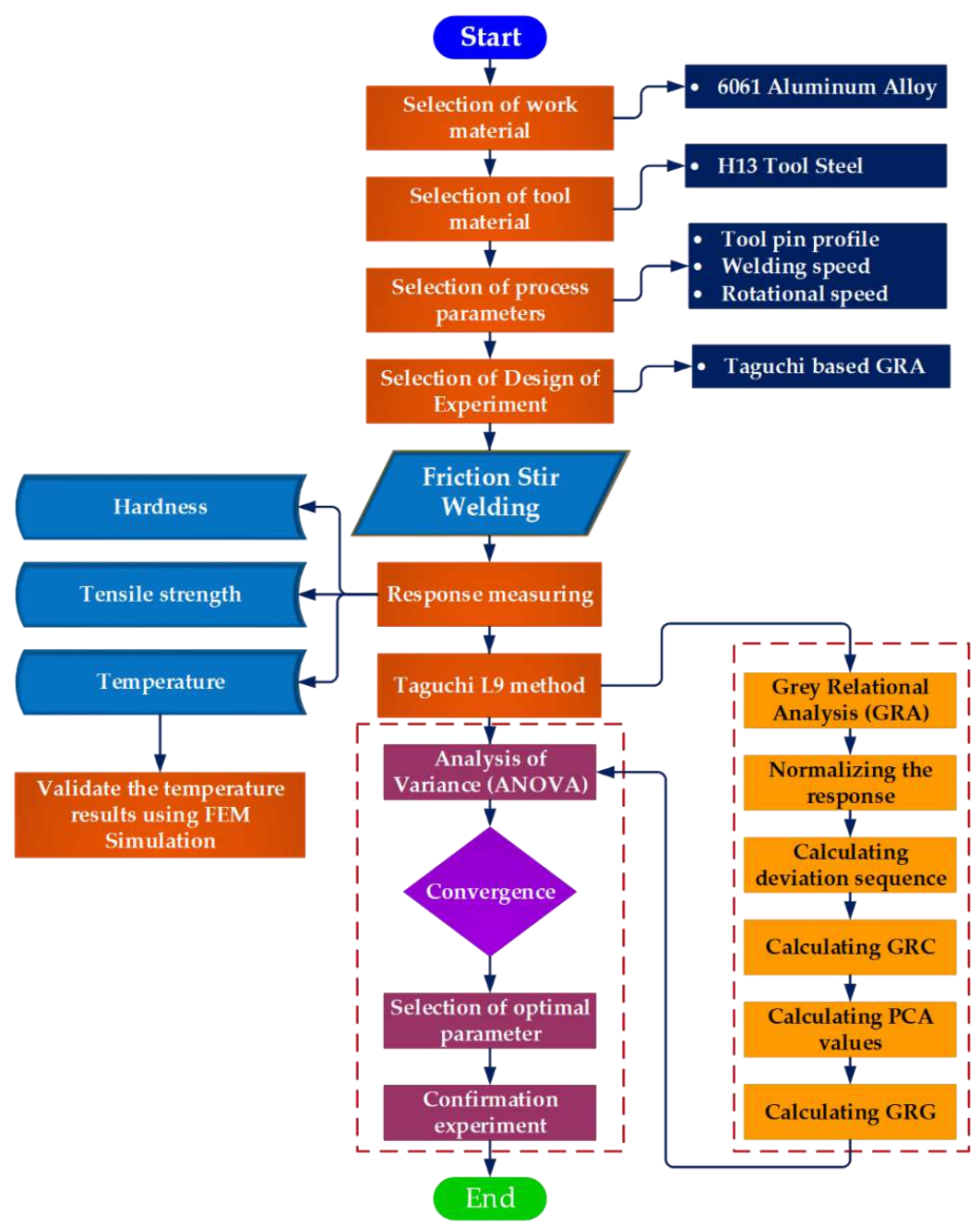

Figure 5. The overall research framework of the study

\subsection{Deviation sequences and Grey Relational Coefficients}

The next step is to find a Grey Relational Coefficient (GRC) using equations 8 and 9, $\xi \mathrm{i}(\mathrm{k})$, from the normalized values. The link between the reference sequence and the comparability sequence is explained using the GRC. To integrate the data obtained from equations 8 and 9 , the GRC $(\xi)$ is determined, and results are displayed in

Table 11 .

$$
\Delta_{0 i}(k)=\left\|x_{0^{*}}(k)-x_{i^{*}}(k)\right\|
$$




$$
\xi i\left(x_{0^{*}}(k), x_{0^{*}}(k)\right)=\frac{\Delta_{\min }(k)+\xi \Delta_{\max }(k)}{\Delta_{0 i}(k)+\xi \Delta_{\max }(k)}
$$

Where $\Delta_{0 i}(k)$ is the deviation sequence of the reference sequence $x_{0^{*}}(k)$ and comparability sequence $x_{i^{*}}(k)$ and $\xi$ is the distinguishing coefficient that takes a value between 0 and 1 , and the value of 0.5 is used based on the principal component analysis result. The deviation sequences are calculated according to equation 8 , and the results are depicted in

Table 7. The deviation sequences must be calculated before the GRC.

Table 7. Normalization and deviation sequence

\begin{tabular}{|c|c|c|c|c|}
\hline \multicolumn{3}{|c|}{$\begin{array}{l}\text { Step 1: Data } \\
\text { normalized }\end{array}$} & \multicolumn{2}{|c|}{ Step 2: Deviation sequence } \\
\hline No & UTM & HRA & UTM & HRA \\
\hline 1 & 0.7039 & 0.4693 & 0.2961 & 0.5307 \\
\hline 2 & 0.7653 & 0.5337 & 0.2347 & 0.4663 \\
\hline 3 & 0.8016 & 0.6849 & 0.1984 & 0.3151 \\
\hline 4 & 0.8256 & 0.7495 & 0.1744 & 0.2505 \\
\hline 5 & 0.8612 & 0.7610 & 0.1388 & 0.2390 \\
\hline 6 & 0.0000 & 0.0000 & 1.0000 & 1.0000 \\
\hline 7 & 1.0000 & 1.0000 & 0.0000 & 0.0000 \\
\hline 8 & 0.4592 & 0.1380 & 0.5408 & 0.8620 \\
\hline 9 & 0.7039 & 0.5007 & 0.2961 & 0.4993 \\
\hline
\end{tabular}

\subsection{Principal component analysis}

The Principal Component Analysis (PCA) has created by Pearson and Hotelling to describe the variance-covariance structure using linear combinations of each quality feature. In terms of variance, it lines up in descending order, and the first principal component accounts for the largest variance in the data. The matrix comprises of Eigenvalues, Eigenvectors, and quality characteristics contributions [35-37]. For subsequent analysis, the principal component with the greatest Eigenvalues was chosen to replace the original responses. In this study, the highest Eigenvalues were found in the UTS first principal component. Table 8Table 9Table 10 illustrates the contribution of each quality feature to the first main components.

Table 8. Eigenvalues and explained variation

\begin{tabular}{ccc}
\hline Step 3: Principal component & Eigenvalues & Explained Variation (\%) \\
\hline UTS & 1.9571 & 97.9 \\
HRA & 0.0429 & 2.1 \\
\hline
\end{tabular}

Table 9. The Eigenvectors for principal component

\begin{tabular}{ccc}
\hline Quality characteristic & \multicolumn{2}{c}{ Eigenvector } \\
& $\begin{array}{c}\text { 1st } \\
\text { principal }\end{array}$ & $\begin{array}{c}\text { 2nd } \\
\text { principal }\end{array}$ \\
\hline UTS & 0.707 & 0.707 \\
HRA & 0.707 & -0.707 \\
\hline
\end{tabular}

Table 10. Quality characteristic contribution

\begin{tabular}{r|l}
\hline UTS & 0.4999 \\
HRA & 0.4999 \\
\hline
\end{tabular}

As a result, the grey relationship coefficients values of 0.5 are utilized.

\subsection{Grey Relational Grade}

The Grey Relational Grade (GRG) shows the correlation between the reference sequence and the comparability sequence. It is a weighted average of the grey relational coefficients of multi-objective [38]. The mathematical equations for determining GRG are depicted in equation 10, and its results are shown in

Table 11 . 


$$
\gamma i\left(x_{0^{*}}, x_{1^{*}}\right)=\frac{1}{n} \sum_{i=1}^{n} w i \xi\left(x_{0^{*}}(k), x_{i^{*}}(k)\right)
$$

Where $\gamma \mathrm{i}\left(x_{0^{*}}, x_{1^{*}}\right)$ is the GRG for the $\mathrm{i}^{\text {th }}$ experiment, $w_{i}$ is the weighting value of the $\mathrm{i}^{\text {th }}$ performance characteristic, and $\mathrm{n}$ is the number of performance characteristics.

Table 11. GRC and GRD

\begin{tabular}{ccccc}
\hline \multicolumn{3}{c}{$\begin{array}{c}\text { Step 4: Grey relational } \\
\text { Coefficient }\end{array}$} & $\begin{array}{c}\text { Step 5: Grey relational grade } \\
\text { and it is rank }\end{array}$ \\
No & UTM & HRA & GRG & Rank \\
\hline 1 & 0.6280 & 0.4851 & 0.5566 & 7 \\
2 & 0.6805 & 0.5174 & 0.5990 & 5 \\
3 & 0.7159 & 0.6134 & 0.6647 & 4 \\
4 & 0.7414 & 0.6663 & 0.7038 & 3 \\
5 & 0.7828 & 0.6766 & 0.7297 & 2 \\
6 & 0.3333 & 0.3333 & 0.3333 & 9 \\
7 & 1.0000 & 1.0000 & 1.0000 & 1 \\
8 & 0.4804 & 0.3671 & 0.4237 & 8 \\
9 & 0.6280 & 0.5004 & 0.5642 & 6 \\
\hline \multicolumn{5}{c}{ Average GRG = 0.6194 } \\
\hline
\end{tabular}

Table 12. Main Effects of GRG

\begin{tabular}{cccc}
\hline Level & $\begin{array}{c}\text { Tool Profile } \\
(\mathrm{A})\end{array}$ & $\begin{array}{c}\text { Welding Speed } \\
(\mathrm{B})\end{array}$ & $\begin{array}{c}\text { Rotational Speed } \\
(\mathrm{C})\end{array}$ \\
\hline 1 & 0.6067 & 0.7535 & 0.4379 \\
2 & 0.5889 & 0.5841 & 0.6223 \\
3 & 0.6626 & 0.5207 & 0.7981 \\
Delta & 0.0737 & 0.2327 & 0.3602 \\
\hline Rank & 3 & 2 & 1 \\
\hline
\end{tabular}
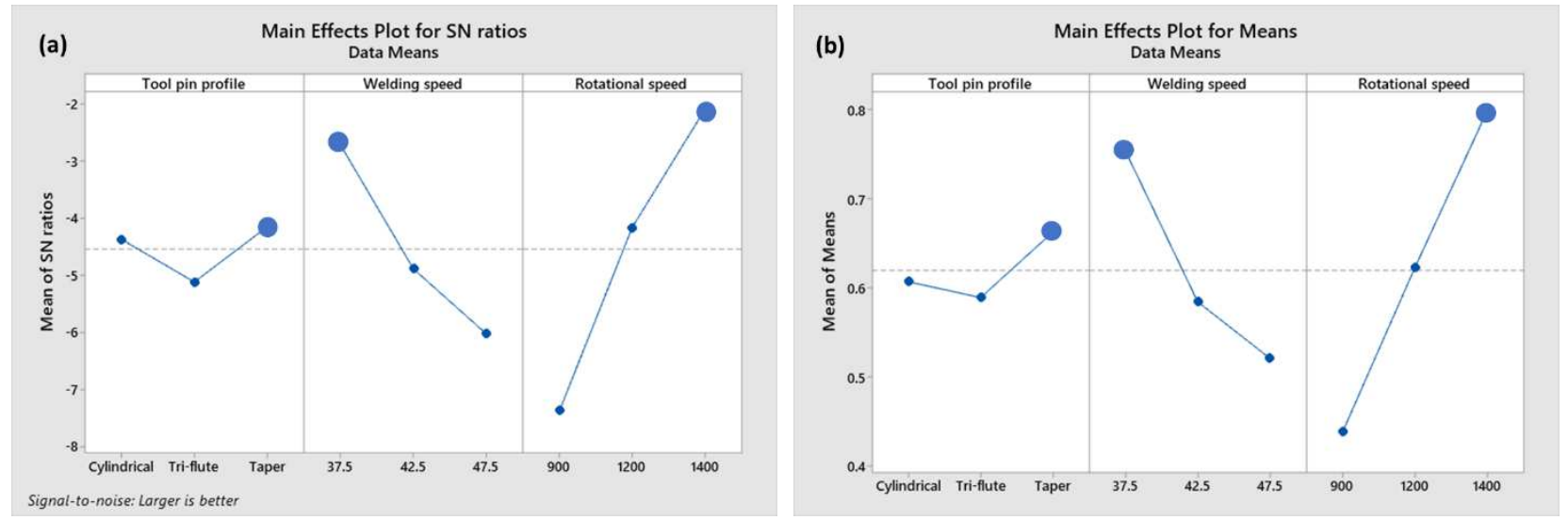

Figure 6. Combination of optimal parameters (a) S/N ratio of GRG (b) Main effects of GRG

Figure $6 \mathrm{~b}$ indicates the optimal combination of parameters and their levels obtained $\mathbf{A}_{\mathbf{3}} \mathbf{B}_{\mathbf{1}} \mathbf{C}_{3}$, i.e., a tapered threaded tool pin profile, traverse speed of $37.5 \mathrm{~mm} / \mathrm{min}$, and tool rotational speed of $1400 \mathrm{~mm} / \mathrm{min}$ at the optimum condition. The result obtained from the Taguchi-based GRA has similar to the simulation study results.

\subsection{Analysis of Variance (ANOVA)}

In this study, to determine whether the parameter was significant or not, ANOVA was used, and its results are summarized in Table 13. The P-value of rotational and traverse speed is less than 0.05, and the F-vales are greater than the standard table reading of the F-value. Therefore, rotational and traverse speeds are significant parameters at $95 \%$ of the confidence interval. Their percentage of contribution of the parameters is the rotational speed of $(64.21 \%)$. The traverse speed of $(27.49 \%)$ contributes to getting a sound weld joint. Due to uncertain or unpredictable circumstances, the total error pooled can be used to determine whether or not an experiment is feasible and sufficient. As indicated in 
Table 13, the error pooled contribution is 8.291 percent, indicating that the proposed optimization strategy and the study's results are highly acceptable.

Table 13. Results of an ANOVA for a grey relational grade (GRG)

\begin{tabular}{|c|c|c|c|c|c|c|c|}
\hline - & DF & Adj SS & Adj MS & F-Value & P-Value & Contribution & Remark \\
\hline Tool Profile* & 2 & 0.008875 & 0.004438 & 1.45795 & 0.271 & & Insignificant \\
\hline Welding Speed & 2 & 0.08685 & 0.043425 & 14.26577 & 0.037 & 27.49644217 & Significant \\
\hline Rotational Speed & 2 & 0.194691 & 0.097346 & 31.97963 & 0.017 & 64.21227163 & Significant \\
\hline Error & 2 & 0.003301 & 0.001651 & & & & \\
\hline Error pooled & 4 & 0.012176 & 0.003044 & & & 8.291 & \\
\hline Total & 8 & 0.293718 & & & & $100 \%$ & \\
\hline \multicolumn{8}{|c|}{$F_{0.05}(2,4)=6.94$} \\
\hline & & $\mathrm{S}$ & R-sq & R-sq(adj) & R-sq(pred) & & \\
\hline & & 0.0406277 & $98.88 \%$ & $95.50 \%$ & $77.24 \%$ & & \\
\hline
\end{tabular}

\subsection{Confirmation Experiment}

The confirmation test was performed on ten samples under the optimal parameter settings of $A_{3} B_{1} C_{3}$. A 95\% confidence interval was used to predict the mean of grey relational grade. The following equations were used to produce the anticipated mean of grey relational grade $(\mu \mathrm{GRG})$ on a confirmation test [37].

$$
\mu \mathrm{A} 1 \mathrm{~B} 2=\dot{\Gamma} \mathrm{GRG}+\left(\mathrm{A}_{1}-\dot{\Gamma} \mathrm{GRG}\right)+\left(\mathrm{B}_{2}-\dot{\Gamma} \mathrm{GRG}\right)=\mathrm{A} 1+\mathrm{B}_{2}-\dot{\Gamma} \mathrm{GRG}
$$

Where $\Gamma$ GRG is the overall mean of grey relational grade $=0.6194, \Gamma$ GRG is equal to the overall mean of grey relational grade $=0.6194$. $A_{1}$ and $B_{2}$ are the mean values of grey relational grade with parameters at optimum levels.

$$
\mu=0.7535+0.7981-0.6194=\mathbf{0 . 9 3 2 2}
$$

The following equation is used to calculate the confidence interval for the expected mean on a confirmation run [39].

$$
\mathrm{CI}=\mu \pm \sqrt{F \alpha ;(1 ; f e) * V e\left(\frac{1}{n e f f}+\frac{1}{r}\right)}
$$

Where $F \alpha ;(1, f e)=\mathrm{F}_{0.05} ;(1,4)=\mathbf{7 . 7 1}$

$\alpha=$ Risk $=0.05$

$f e=$ Error $\mathrm{DOF}=4$

$\mathrm{Ve}=$ Error adjusted mean square $=0.003044$

$n_{\text {eff }}=$ Effective number of replications

$\mathrm{R}=$ Number of replications for confirmation experiment $=10$

In addition, the effective number of replications (neff) was calculated by:

$$
n e f f=\frac{T n}{1+T s}=\frac{9}{1+4}=\mathbf{1 . 8}
$$

Where $n e f f=$ is expressed in mathematical

$\mathrm{Tn}=$ Total number of experiments $=9$

Ts $=$ The sum of the total degree of freedom of significant factors.

Therefore, the calculated CI is 


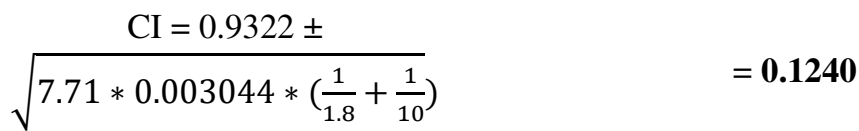

The $95 \%$ confidence interval of the predicted optimal Grey relational grade is

$$
(\mu-\mathrm{CI})<\mu<(\mu+\mathrm{CI})
$$

$$
\begin{gathered}
(0.9322-0.1240)<0.9322<(0.9322+0.1240) \\
=0.8082<0.9322<1.0562
\end{gathered}
$$

\begin{tabular}{|c|c|c|c|c|}
\hline \multirow{2}{*}{$\begin{array}{c}\text { Optimal combination } \\
\qquad \mathrm{A}_{3} \mathrm{~B}_{1} \mathrm{C}_{3}\end{array}$} & \multicolumn{4}{|c|}{ Response of quality characteristics } \\
\hline & UTS & $\mathrm{UTS}_{\mathrm{S} / \mathrm{N}}$ & HRA & $\mathrm{HR}_{\mathrm{S} / \mathrm{N}}$ \\
\hline Test 1 & 49.1273 & 286 & 78.0 & 37.841 \\
\hline Test 2 & 49.1576 & 287 & 78.0 & 37.841 \\
\hline Test 3 & 49.1576 & 287 & 77.6 & 37.797 \\
\hline Test 4 & 49.1576 & 287 & 78.0 & 37.841 \\
\hline Test 5 & 49.1576 & 287 & 78.0 & 37.841 \\
\hline Test 6 & 49.1576 & 287 & 78.0 & 37.841 \\
\hline Test 7 & 49.1576 & 287 & 78.0 & 37.841 \\
\hline Test 8 & 49.1576 & 287 & 78.0 & 37.841 \\
\hline Test 9 & 49.1576 & 287 & 78.0 & 37.841 \\
\hline Test 10 & $\begin{array}{c}49.1576 \\
4\end{array}$ & 286 & 78.0 & 37.841 \\
\hline & $r \operatorname{conf}$ & 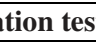 & 0.93 & \\
\hline
\end{tabular}

Table 14. Results of confirmation tests

According to the DOE rule, the number of confirmation experiments must be greater than or equal to the number of experiments [40]. Therefore in this study, the confirmation experiment has taken ten times at the optimal parameter settings. The predicted GRG at optimal condition is obtained between 0.8082 to 1.0562 at a $95 \%$ confidence interval. The grey relational grade for the experiment is 0.9323 , with hardness and tensile strength of 286.8 MPa and 77.96 HR, respectively, as shown in Table 14. As a consequence, the confirmatory experiment tests indicate that the experiment was safest.

\subsection{Simulation vs. Experimental result}

In this study, the experimental parameters and their levels are obtained from the simulation results. The maximum temperature recorded on the simulation and experiment has $559.9{ }^{\circ} \mathrm{C}$ and $554.0{ }^{\circ} \mathrm{C}$, respectively, summarized in Table 15 , at the optimum parameter settings. The percent variation between the simulation and experimental results is $1.1 \%$; the two results are very close. Predicting the effect of parameters using a finite element method can minimize the trial and error experimentations.

Table 15. Simulation vs. Experimental parameters and results

\begin{tabular}{cccc}
\hline Parameters & Simulation results & Experimental results & \% of temperature Variation \\
\hline Tool pin profile & Taper threaded tool & Taper threaded tool & - \\
Welding speed & $0.625 \mathrm{~mm} / \mathrm{sec}$ & $37.5 \mathrm{~mm} / \mathrm{min}$ & - \\
Rotational speed & $1400 \mathrm{rpm}$ & $1400 \mathrm{rpm}$ & - \\
Shoulder radius & $7 \mathrm{~mm}$ & $7 \mathrm{~mm}$ & - \\
Pin radius & $2.5 \mathrm{~mm}$ & $2.5 \mathrm{~mm}$ & - \\
Weld length & $50 \mathrm{~mm}$ & $50 \mathrm{~mm}$ & - \\
$\mathrm{N}^{\circ}$ of steps & 200 & - & - \\
Temperature result & $559.9^{\circ} \mathrm{C}$ & $554.0^{\circ} \mathrm{C}$ & $1.1 \%$ \\
\hline
\end{tabular}

\subsection{Metallographic Characterization}

A metallographic characterization was executed with the optimized process parameters to examine the microstructure changes between the weld and the base metal. The result revealed that no significant differences nor quantifiable volumetric flaws were observed in the macrographs. It was showing similar macrostructural characteristics for all examined welds. All of the usual FSW microstructural weld zones, such as the stirred zone (SZ), illustrated in Figure 7 , thermo-mechanically affected zone (TMAZ), heat-affected zone (HAZ), and parent metal, showed good soundness (PM). 


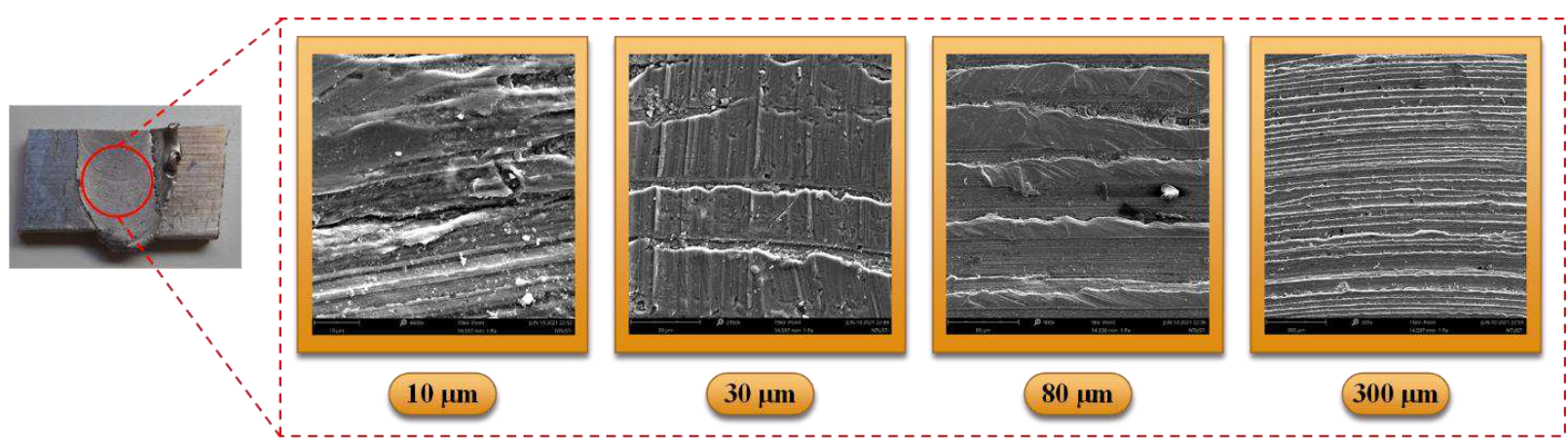

Figure 7. Scanning Electron Microscope result at different resolutions

\section{Conclusion}

This study used Taguchi and GRA to perform multi-objective optimization to find the optimal process parameters for friction stir welding 6061 aluminum alloy. The ultimate tensile strength and hardness of the joint are used to assess the weld's quality. The investigation's results can be summarized as follows:

i. The impact of input welding parameters on the quality of friction stir welded joint was demonstrated and analyzed. At a rotational speed of $1400 \mathrm{rpm}$ with a traverse speed of $37.5 \mathrm{~mm} / \mathrm{min}$ and a tapered tool pin profile, the maximum tensile strength, and hardness of the joint, 286.8 MPa and 77.96 HRA, respectively, were measured. The joint's minimum tensile strength and hardness were also measured at a rotating speed of 900 $\mathrm{rpm}$, a traverse speed of $47.5 \mathrm{~mm} / \mathrm{min}$, and a tri-flute threaded tool.

ii. A sound weld is achieved using taper threaded tools with a rotating speed of $900 \mathrm{rpm}$ and a $37.5 \mathrm{~mm} / \mathrm{min}$ traverse speed.

iii. According to the ANOVA results, rotational and welding speed each contribute 64.2 percent and 27.4 percent to the joint quality of the weld, respectively.

iv. With a higher tool rotating speed, a lower welding speed, and a taper tool pin profile, the quality of the weld improved.

v. The ability and sufficiency of Taguchi-based GRA for investigating friction stir welded the conformability of the projected results demonstrates AA 6061. The experiment's highest efficiency (when utilizing the optimum value of the input parameter) is $92.25 \%$.

vi. An essential parameter for creating the requisite heat is the combination of rotational speed and welding speed. In the optimum parameter setting, the maximum temperature of $559.9^{\circ} \mathrm{C}$, which is $(14.12 \%)$ less than the liquid temperature of the base material of AA $6061\left(652^{\circ} \mathrm{C}\right)$, was obtained in the simulation. Both experimental and simulation results are quite similar, indicating that welding temperature is highly influenced by rotational and welding speed. In addition to this, the welding temperature having a significant effect on the thermo-mechanical properties of the weld joints. The temperature-based simulation result of each parameter and level is similar to the optimized Taguchi-based GRA optimal parameter settings results.

vii. No significant differences nor quantifiable volumetric flaws were observed in the macrographs, showing similar macrostructural characteristics for all the examined welds. All welds exhibited good soundness with all the typical FSW microstructural weld zones such as the stirred zone, thermo-mechanically affected zone, heataffected zone, and parent metal.

\section{Declaration \\ Funding}

This research did not receive any specific grant from funding agencies in the public, commercial, or not-for-profit sectors.

\section{Conflict of Interest}

The authors declare that they have no competing personal and financial interests.

Availability of data and material: Not applicable.

Code availability: Not applicable.

Ethics approval Not applicable.

Consent to participate Not applicable.

Consent for publication Not applicable.

Credit authorship contribution statement:

EMS: Conceptualization, Methodology, writing an original draft, making simulation, review \& editing the whole paper. AAT: Conceptualization, Supervision, Structure of the overall framework, review, and editing the whole paper. All authors have read and agreed to the published version of the manuscript. 
[1] P. Kah, R. Rajan, J. Martikainen, and R. Suoranta, "Investigation of weld defects in friction-stir welding and fusion welding of aluminium alloys," International Journal of Mechanical and Materials Engineering, vol. 10, no. 1, pp. 1-10, 2015.

[2] M. M. A. Elnabi, T. A. E. Osman, A. E. El Mokadem, and A. B. Elshalakany, "Mechanical Properties and Microstructure of Dissimilar Friction Stir Welding of Pure Aluminum to Low Carbon Steel," Advanced Journal of Graduate Research, vol. 4, no. 1, pp. 47-58, 2018, doi: https://doi.org/10.21467/ajgr.4.1.47-58.

[3] O. S. Salih, N. Neate, H. Ou, and W. Sun, "Influence of process parameters on the microstructural evolution and mechanical characterisations of friction stir welded Al-Mg-Si alloy," Journal of Materials Processing Technology, vol. 275, p. 116366, 2020, doi: https://doi.org/10.1016/j.jmatprotec.2019.116366.

[4] P. S. a. V. Jaiganesh, "Impact of process parameters during friction stir welding of AZ80A Mg alloy," Science and Technology of Welding and Joining, vol. 00, no. 0, pp. 1-8, 2015, doi: http://DOI.org/10.1179/1362171815Y.0000000068.

[5] V. P. Singh, S. K. Patel, A. Ranjan, and B. Kuriachen, "Recent research progress in solid state friction-stir welding of aluminiummagnesium alloys: a critical review," Journal of Materials Research and Technology, vol. 9, no. 3, pp. 6217-6256, 2020/05/01/ 2020, doi: https://doi.org/10.1016/j.jmrt.2020.01.008.

[6] N. Bhardwaj, R. G. Narayanan, U. Dixit, and M. Hashmi, "Recent developments in friction stir welding and resulting industrial practices," Advances in Materials and Processing Technologies, vol. 5, no. 3, pp. 461-496, 2019, doi: https://doi.org/10.1080/2374068X.2019.1631065.

[7] G. Shinde, S. Gajghate, P. Dabeer, and C. Seemikeri, "Low cost friction stir welding: a review," Journal of Materials Today: Proceedings, vol. 4, no. 8, pp. 8901-8910, 2017.

[8] V. Patel, W. Li, G. Wang, F. Wang, A. Vairis, and P. Niu, "Friction Stir Welding of Dissimilar Aluminum Alloy Combinations: State-ofthe-Art," Journal of Metals, vol. 9, no. 3, pp. 1-19, 2019, doi: https://doi.org/10.3390/met9030270.

[9] H. Shirazi, S. Kheirandish, and H. Pouraliakbar, "Employing hooking and effective sheet thickness to achieve optimum failure load in lap joints of friction stir welded AA5456 aluminum," Journal of Theoretical Applied Fracture Mechanics, p. 102423, 2019, doi: https://doi.org/10.1016/j.tafmec.2019.102423

[10] K. F. a. V. Badheka, "Bobbin tool friction stir welding: a review," SCIENCE AND TECHNOLOGY OF WELDING AND JOINING, pp. 129, 2018, doi: https://doi.org/10.1080/13621718.2018.1553655.

[11] Q. Wu, M. Li, Y. Guo, J. Shan, H. Wang, and Y. Chang, "Microstructural evolution and mechanical properties of friction stir welded 12CrODS steel," Nuclear Materials and Energy, vol. 25, p. 100804, 2020/12/01/ 2020, doi: https://doi.org/10.1016/j.nme.2020.100804.

[12] S. W. Kallee, "5 - Industrial applications of friction stir welding," in Friction Stir Welding, D. Lohwasser and Z. Chen Eds.: Woodhead Publishing, 2010, pp. 118-163.

[13] S. Inaniwa, Y. Kurabe, Y. Miyashita, and H. Hori, "Application of friction stir welding for several plastic materials," in Proceedings of the 1st International Joint Symposium on Joining and Welding, H. Fujii Ed.: Woodhead Publishing, 2013, pp. 137-142.

[14] J. Martin, C. Blacker, K. Beamish, and A. Makaya, "Friction Stir Welding of Fibre-Reinforced Titanium Composites for Aerospace Structures," in Friction Stir Welding and Processing X: Springer, 2019, pp. 43-57.

[15] D. Devaiah, K. Kishore, and P. Laxminarayana, "Optimal FSW process parameters for dissimilar aluminium alloys (AA5083 and AA6061) Using Taguchi Technique," Journal of Materials Today: Proceedings, vol. 5, no. 2, Part 1, pp. 4607-4614, 2018/01/01/ 2018, doi: https://doi.org/10.1016/j.matpr.2017.12.031.

[16] M. S. U. Rahman and L. Jayahari, "Study Of Mechanical Properties and Wear Behaviour of Aluminium 6061 Matrix Composites Reinforced with Steel Machining Chips," Journal of Materials today: Proceedings, vol. 5, no. 9, pp. 20117-20123, 2018.

[17] M. K. Kulekci, "Magnesium and its alloys applications in automotive industry," International Journal of Advanced Manufacturing Technology, vol. 39, no. 9-10, pp. 851-865, 2008, doi: https://doi.org/10.1007/s00170-007-1279-2.

[18] B. T. G. a. D. H. Lammlein, "Friction stir welding: Process, automation, and control," Journal of Manufacturing Processes, vol. 16, pp. 56-73, 2013, doi: http://dx.doi.org/10.1016/j.jmapro.2013.04.002.

[19] B. H. Y. X. Huang, Y. Tian, H. J. Liu, S. X. Lv, J. C. Feng, J. S. Leng and Y. Li, "New technique of filling friction stir welding," Science and Technology of Welding and Joining, vol. 16, no. 6, pp. 497-501, 2011, doi: http://DOI.org/10.1179/1362171811Y.0000000032

[20] P. Prasanna, B. S. Rao, G. K. M. Rao, and A. Prasad, "Experimental and numerical evaluation of friction stir welds of AA6061-T6 aluminium alloy," ARPN Journal of Engineering and Applied Sciences, vol. 5, no. 6, pp. 1-18, 2010.

[21] Y. Li, M.-D. Shieh, C.-C. Yang, and L. Zhu, "Application of Fuzzy-Based Hybrid Taguchi Method for Multi-objective Optimization of Product Form Design," Journal of Mathematical Problems in Engineering, vol. 2018, pp. 1-18, 2018, doi: https://doi.org/10.1155/2018/9091514.

[22] Ş. Kasman, "Optimisation of dissimilar friction stir welding parameters with grey relational analysis," Proceedings of the Institution of Mechanical Engineers, Part B: Journal of Engineering Manufacture, vol. 227, no. 9, pp. 1317-1324, 2013, doi: $10.1177 / 0954405413487729$.

[23] M. P. Alam and A. N. Sinha, "Studies on temperature distribution in friction stir welding of AA7075 T651," in 2018 International Conference on Computational and Characterization Techniques in Engineering \& Sciences (CCTES), 2018: IEEE, pp. 119-121, doi: http://DOI.org/10.1109/CCTES.2018.8674152.

[24] H. Schmidt, J. Hattel, and J. Wert, "An analytical model for the heat generation in friction stir welding," Modelling and simulation in materials science and engineering, vol. 12, no. 1, p. 143, 2003, doi: https://DOI.org/10.1088/0965-0393/12/1/013.

[25] H. Schmidt and J. Hattel, "Modelling heat flow around tool probe in friction stir welding," Science and Technology of Welding and joining, vol. 10, no. 2, pp. 176-186, 2005, doi: https://doi.org/10.1179/174329305X36070. 
[26] Y. J. Chao, X. Qi, and W. Tang, "Heat transfer in friction stir welding—experimental and numerical studies," J. Manuf. Sci. Eng., vol. 125, no. 1, pp. 138-145, 2003, doi: https://doi.org/10.1115/1.1537741.

[27] J. H. Hattel, H. Schmidt, and C. Tutum, "Thermomechanical modelling of friction stir welding," in ASM Proceeding of International Conference: Trends in Welding Researches, 2009, vol. 1, no. 1, pp. 1-10, doi: http://DOI.org/10.1361/cp2008twr001.

[28] Y. Wang, "Study on Influence Factors of zinc layer thickness via Response Surface Method, Taguchi Method and Genetic Algorithm," Journal of Industrial Engineering \& Management, vol. 7, no. 1, pp. 1-10, 2018, doi: http://DOI.org/10.4172/2169-0316.1000245.

[29] V. K. Sharma, Q. Murtaza, S. Garg, and Management, "Response Surface Methodology \& Taguchi Techquines to Optimization of CNC Turning Process," International Journal of Production Technology, vol. 1, no. 1, pp. 13-31, 2010

[30] N. Ghetiya, K. Patel, and A. Kavar, "Multi-objective optimization of FSW process parameters of aluminium alloy using Taguchi-based grey relational analysis," Transactions of the Indian Institute of Metals, vol. 69, no. 4, pp. 917-923, 2016, doi: http://DOI.org/10.1007/s12666-015-0581-1.

[31] J. Kundu and H. Singh, "Friction stir welding of AA5083 aluminium alloy: Multi-response optimization using Taguchi-based grey relational analysis," Journal of Advances In Mechanical Engineering, vol. 8, no. 11, p. 1687814016679277, 2016, doi: http://DOI.org/10.1177/1687814016679277.

[32] P. Joshi and A. Sharma, "Simultaneous optimization of kerf taper and heat affected zone in Nd-YAG laser cutting of Al 6061-T6 sheet using hybrid approach of grey relational analysis and fuzzy logic," Precision Engineering, vol. 54, pp. 302-313, 2018/10/01/ 2018, doi: https://doi.org/10.1016/j.precisioneng.2018.06.007.

[33] S. Vijayan, R. Raju, and S. K. Rao, "Multi-objective optimization of friction stir welding process parameters on aluminum alloy AA 5083 using Taguchi-based grey relation analysis," Journal of Materials and Manufacturing Processes, vol. 25, no. 11, pp. 1206-1212, 2010, doi: http://dx.doi.org/10.1080/10426910903536782.

[34] S. Sheth and P. M. George, "Experimental investigation, prediction and optimization of cylindricity and perpendicularity during drilling of WCB material using grey relational analysis," Precision Engineering, vol. 45, pp. 33-43, 2016/07/01/ 2016, doi: https://doi.org/10.1016/j.precisioneng.2016.01.002.

[35] H. Lu, C. Chang, N. Hwang, and C. Chung, "Grey relational analysis coupled with principal component analysis for optimization design of the cutting parameters in high-speed end milling," Journal of materials processing technology, vol. 209, no. 8, pp. 3808-3817, 2009, doi: http://doi.org/10.1016/j.jmatprotec.2008.08.030

[36] A. N. Siddiquee, Z. A. Khan, and Z. Mallick, "Grey relational analysis coupled with principal component analysis for optimisation design of the process parameters in in-feed centreless cylindrical grinding," The International Journal of Advanced Manufacturing Technology, vol. 46, no. 9-12, pp. 983-992, 2010, doi: http://DOI.org10.1007/s00170-009-2159-8.

[37] C.-P. Fung and P.-C. Kang, "Multi-response optimization in friction properties of PBT composites using Taguchi method and principle component analysis," Journal of Materials Processing Technology, vol. 170, no. 3, pp. 602-610, 2005/12/30/ 2005, doi: https://doi.org/10.1016/j.jmatprotec.2005.06.040.

[38] S. Wojciechowski, R. W. Maruda, G. M. Krolczyk, and P. Niesłony, "Application of signal to noise ratio and grey relational analysis to minimize forces and vibrations during precise ball end milling," Precision Engineering, vol. 51, pp. 582-596, 2018/01/01/ 2018, doi: https://doi.org/10.1016/j.precisioneng.2017.10.014.

[39] M. Gupta and S. Kumar, "Multi-objective optimization of cutting parameters in turning using grey relational analysis," International Journal of Industrial Engineering Computations, vol. 4, no. 4, pp. 547-558, 2013, doi: http://DOI.org/10.5267/j.ijiec.2013.06.001.

[40] W. A. Jensen, "Confirmation runs in design of experiments," Journal of Quality Technology, vol. 48, no. 2, pp. 162-177, 2016, doi: https://doi.org/10.1080/00224065.2016.11918157. 


\section{Supplementary Files}

This is a list of supplementary files associated with this preprint. Click to download.

- Graphicalabstractsubmission.pptx 